\title{
The Role of Self-Control and Self-Adjustment on Academic Achievement Among Junior High School Students
}

\author{
Asep Agung Judistira \\ Department of Psychology \\ Islamic University of Indonesia, Yogyakarta, Indonesia \\ asep.agung@uii.ac.id
}

\author{
Hariz Enggar Wijaya \\ Department of Psychology \\ Islamic University of Indonesia, Yogyakarta, Indonesia \\ hariz.wijaya@uii.ac.id
}

\begin{abstract}
Attaining high academic achievement, not only merely about excellent teaching and instruction, but also the psychological factor of students itself. The aim of this research is to find out the role of self-control and self-adjustment on the academic achievement of junior high school students. There were 96 first year students of Islamic boarding school in Tasikmalaya enrolled this study, $48.96 \%$ of them were males and $51.04 \%$ females. Data were collected by using The Brief Self-Control Scale, Self-Adjustment Scale, and also the final grade of school report. Data analysis showed that both selfcontrol and self-adjustment correlate with student academic achievement. For further analysis, multiple regression showed that only self-control could predict academic achievement. Also reported from data analysis that boys and girls are different significantly in academic achievement, self-control, and self-adjustment.
\end{abstract}

Keywords: self-control, self-adjustment, academic achievement, junior high school students

\section{INTRODUCTION}

It is undeniable that academic achievement plays a central issue in education. Most of all educational institution serve this achievement as a learning attaining, bothstate or private institution. In the government context, academic achievement operationalized by state examination grade that reflect how far student take advantage of schooling. Although learning process is not always visible, it can be measured by score or grade like GPA, final examination, or school report, which in turn we called it academic achievement.

Academic achievement has been widely studied. It is well establish that cognitive ability display an important role of academic achievement. Jensen (1998) has reported the strong association of intelligence and achievement. Neisser et al., (1996) highlighted, even IQ score correlates moderately with students achievement $(r=0,50)$, it's only explain $25 \%$ of the overall variance. Similar with those, Duckworth and Seligman (2005) reported the correlation between IQ and final GPA of middle school students $(r=0.30)$. Also, Rohde and Thompson (2007) showed the correlation between general cognitive ability correlate and academic achievement (GPA) of undergraduate students $(\mathrm{r}=0.375)$.

Not only cognitive ability, recent studies has revealed the important role of non-cognitive factors on academic success. Such Zimmerman and Kitsantas (2014) found, self-discipline and self-regulation could predict student achievement. Others researchers found academic discipline as a good predictor of achievement (Komarraju, Ramsey, \& Rinella, 2013). Another noncognitive factors affecting students achievement are self-efficacy, academic motivation, self-regulation, effort regulation (Robbins, Lauver, Le, Davis, \& Carlstrom, 2004; Richardson, Abraham, \& Bond, 2012; Agustiani, Cahyadi, \& Musa, 2016). Interestingly, some researchers reported that self-discipline affect achievement beyond cognitive ability (Duckworth \& Seligman, 2005; Stadler, Aust, Becker, Niepel, \& Greiff, 2016).
According to Vohs and Baumeister (2004), selfcontrol refers to person ability in suppressing or inhibiting behaviors or responses intentionally and consciously. It has two domains of control: mental and emotion. Self-control also defines as one's capability to change responses with regard of standards such ideals, moral, values, and social expectations, in pursuing long-term targets (Baumeister, Vohs, \& Tice, 2007). A study conducted by Tangney, Baumeister, and Boone, (2004) indicates that self-control not only could predict GPA, but also better adjustment, better interpersonal, secure attachment, and more optimal emotional responses. Person who has high trait self-control reported not only merely can resisting temptation, but also avoiding (Ent, Baumeister, \& Tice, 2015).

Personal adjustment is another non-cognitive factors which needed to adapt new situation or circumstances, especially for first year students. Within the transition school or class, students need to achieve the new demands or standards of school or class, such as assignments, roles, or achievements. Students who fail to make adjustment, they would be have a problem at school and academic demands. A survey reported by Kusdiyati and Halimah (2011), indicates that many high school student had a problem to make academic adjustment. It reported that $52.5 \%$ of 181 students could not be well adjusted at Pasundan High School. Transition from elementary school to middle school also reported could increase psychological distress or decreased academic achievement following the transition (Chung, Elias, \& Schneider, 1998). If students can make well adjustment, they would have more chance to success, just as reported by Safura and Supriyantini (2006) at Junior High School Medan, showed that self-adjustment had a positive correlation with academic achievement.

To address this issue, we conduct an investigation to evaluate the role of self-control and sel-adjustment on academic achievement.

\section{METHODS}

The participants of current study were 96 firstyear of Islamic junior high school in Tasikmalaya, with 
academic year 2016/2017. There are 47 boys and 49 girls, which has an age range from twelve to thirteen. In order to get students achievement data, we use the book of school grade report. Two scales consist of selfadjustment and self-control were administrated.

Self-adjustment was measured by using Fascaly (2015) self-adjustment scale which composed based on the self-adjustment aspects of Runyon and Haber (1984). The self-adjustment scale consist of 32 items, which used Likert responses. There are five alternative responses, ranging from strongly disagree, disagree, hesitation, agree, and strongly agree. It has Cronbach's $\alpha=0,896$. Self-Control was measured by using The Brief Self-Control Scale translated from Tangney, Baumeister, and Boone (2004). The Brief Self-Control Scale is the short version from The Self-Control Scale which has origin items 36 . The Brief version consists of 13 items which has Cronbach's $\alpha=0.83$. This scale response also use Likert model, which has five alternatives responses: strongly disagree, disagree, hesitation, agree, strongly agree.

The self-report questionnaires were given to the eight grade of junior high school students. Two classes participating this research were first having a letter of permission from headmaster school. At the beginning of class, researcher introduced and asked the students for their cooperation and pay attention. Then the researcher explained the purpose of the study was to gather information on their learning behavior. Before the students fill out the questionnaires, instruction was given. They were told that there were no wrong or right answers. All of their answers would be confidential.

The Pearson correlation coefficient was applied to determine the relationship between the data. A stepwise regression analysis was employed in order to determine if the self-control and self-adjustment predict students academic achievement.

\section{RESULT AND DISCUSSION}

The results given in the Table 1 show that both self-control and self-adjustment correlate significantly with academic achievement $(\mathrm{r}=.256, \mathrm{p}<.05$ and $\mathrm{r}=.254$, $\mathrm{p}<.05)$. The self-control explains $6.6 \%$ of the academic achievement variance and self-adjustment explains $6.4 \%$ academic achievement variance.

A stepwise multiple regression (Table 2) was applied to find out which construct of two scales were significant in predicting student academic achievement. The data analysis showed that when both of the selfcontrol and self-adjustment analyzed together, only self-control could predict academic achievement $(\beta=$ $0.182 ; \mathrm{F}=6.620 ; \mathrm{df}=1 ; \mathrm{p}<0.05)$. It can explain 6.6 percent of the variance in school grade report. For further analysis, gender difference also taken. Table 3 show that there were different significantly between boys and girl on self-control, self-adjustment, and school grade report, whereas girls reported better than boys.

The main goal of this study is to explore the role of self-control and self-adjustment on academic achievement among junior high school students. The result shows that both self-control and self-adjustment correlate positively and significant with academic achievement. Of two constructs, only self-control could predict academic achievement. This finding support previous studies, which again, underline the influence of non-cognitve factors such self-control on academic achievement (Tangney, Baumeister, \& Boone, 2004; Duckworth \& Seligman, 2005; Komarraju et al., 2013; Stadler et al., 2016). Also, it is consistent with Safura and Supriyantini (2006) study, that shown selfadjustment associate positively with student achievement.

Table 1

Correlation between Self-Control, Self-Adjusment, and Academic Achievement
\begin{tabular}{|l|r|r|}
\hline Variable & r & R square \\
\hline self-control & $0.256^{*}$ & 0.066 \\
\hline self-adjustment & $0.254^{*}$ & 0.064 \\
\hline
\end{tabular}

*Correlation is significant at the 0.05 level (2-tailed)

Table 2

Multiple Regression of Self-control and self-adjustment

ANOVA $^{\mathrm{a}}$

\begin{tabular}{|l|l|c|c|c|c|c|}
\hline \multicolumn{2}{|c|}{ Model } & $\begin{array}{c}\text { Sum of } \\
\text { Squares }\end{array}$ & df & Mean Square & F & Sig. \\
\hline \multirow{2}{*}{1} & Regression & 132.157 & 1 & 132.157 & 6.620 & $.012^{\mathrm{b}}$ \\
\cline { 2 - 8 } & Residual & 1876.578 & 94 & 19.964 & & \\
\cline { 2 - 8 } & Total & 2008.735 & 95 & & & \\
\hline
\end{tabular}

a. Dependent Variable: school grade report

b. Predictors: (Constant), self-control

Coefficients $^{\mathrm{a}}$

\begin{tabular}{|c|c|c|c|c|c|}
\hline & & Coeffic & & & \\
\hline \multirow[t]{2}{*}{ Model } & \multicolumn{2}{|c|}{$\begin{array}{c}\text { Unstandardized } \\
\text { Coefficients }\end{array}$} & $\begin{array}{c}\text { Standardized } \\
\text { Coefficients }\end{array}$ & \multirow[t]{2}{*}{$\mathrm{t}$} & \multirow[t]{2}{*}{ Sig. } \\
\hline & $\mathrm{B}$ & Std. Error & Beta & & \\
\hline \multirow{2}{*}{\begin{tabular}{|l|l|}
1 & (Constant) \\
\cline { 2 - 2 } & Self-control \\
\end{tabular}} & 70.900 & 3.018 & & 23.492 & .000 \\
\hline & .182 & .071 & .256 & 2.573 & .012 \\
\hline
\end{tabular}


Table 3

\begin{tabular}{|l|c|c|c|c|c|c|}
\hline \multicolumn{1}{|c|}{ Independent Samples Test } \\
\hline Self- & Gender & $\mathrm{N}$ & Mean & $\begin{array}{c}\text { Mean } \\
\text { Difference }\end{array}$ & $\mathrm{t}$ & $\begin{array}{c}\text { Sig } \\
\text { (2-tailed) }\end{array}$ \\
\hline adjustment & boys & 47 & 73.19 & -4.52 & -2.117 & .037 \\
\cline { 2 - 8 } School grade & girls & 49 & 77.71 & & & \\
\cline { 2 - 8 } & boys & 47 & 76.73 & -3.61 & -4.161 & .000 \\
\hline \multirow{2}{*}{ Self-control } & girls & 49 & 80.34 & & & \\
\cline { 2 - 8 } & boys & 47 & 40.08 & -3.94 & -3.113 & .002 \\
\hline
\end{tabular}

As Ent et al., (2015) explained, self-control not only matter of restrain one's desire and temptation, but also need to take any action in pursuing one's goal. When students achieving academic demands and target, such assignment, examination, group homework, etc., they need to be focus and aware of any distraction. Temptations to have fun with friend, hangout, seeking pleasure by overriding school tasks would contra productive with academic attaining. One's who possess high self-control would get more advantage than the lower one's. Just as shown by Tangney et al., 2004b that high self-control associated with good self-adjustment, including reduced psychopathology, improve self-esteem, and better grade.

Transition from primary to junior high school believed have potential problem. As new expectations and demands come, psychological distres may arise. Both boys and girls reported have significant increase in psychological distress (Chung et al., 1998). According to longitudinal study of Riglin, Frederickson, Shelton, and Rice (2013), the first year of junior high school adjustment could predict later academic achievement. Students would have more benefit when they could manage this period. How they adapt with school anxiety, school liking, school concern and conduct problems influence their academic achievement.

Personal adjustment in the term of social cognitive theory, view as interconnection between three domains: behavior, cognition, and emotion (Maddux, 2009). Adjustment on school take place when new students face new situation, friends, and school. This social and academic change will encourage change on those three domains. It means students need to adjust their thinking, feeling, and behavior to fulfill academic attaining. This adaptive strategies lead to strive achievement.

Another finding in this study was gender role on self-control, self-adjustment, and achievement. All of three comparation, girls showed better than boys, differ from Zimmerman and Kitsantas (2014) study which reveal no significant gender difference. This finding support previous studies (Safura \& Supriyantini, 2006; Chung et al., 1998) that boys and girl have differences in adjustment, self-control, and achievement. The different result which seem to be inconsistent with previous studies, view as reflection of the diversity in our culture and social identity. Individual differences, including gender here, play an important role in education.
Limitation of this study need to be noted. First, the sample of the study only taken from one junior high school in Tasikmalaya, which have setting Islamic boarding school. Generalization of this finding must take cautiously. Specific result may differ from other sample. Second, this correlation study obtain from selfreport, which has limitation such social desirability bias.

\section{CONCLUSION}

Finding on this research underline that both self-control and self-adjustment associate positively with academic achievement, but from regression analysis suggest only self-control can predict achievement. Gender differences influence on students achievement, also on self-control and adjustment. This results should be consider in education process, especially on transition period from elementary to junior high school. School as an educational institution may take initiative to support this transition. Because boys and girls differ in the way they respon this transition, school need to aware of it. Treatment to date the transition problem may differ by gender differences.

\section{REFERENCES}

[1] Agustiani, H., Cahyadi, S., \& Musa, M. 2016. Selfefficacy and Self-Regulated Learning as Predictors of Students. The Open Psychology Journal, 9(1), 1-6.

[2] Baumeister, R. F., Vohs, K. D., \& Tice, D. M. 2007. The Strength Model of Self-Control. Current Directions in Psychological Science, 16(6), 351-355. https://doi.org/10.1111/j.1467-8721.2007.00534.

[3] Chung, H., Elias, M., \& Schneider, K. 1998. Patterns of Individual Adjustment Changes during Middle School Transition. Journal of School Psychology, 36(1), 83101. https://doi.org/10.1016/S0022-4405 (97)00051-4.

[4] Duckworth, A. L., \& Seligman, M. E. P. 2005. SelfDiscipline Outdoes IQ in Predicting Academic Performance of Adolescents. Psychological Science, 16(12), 939-944. https://doi.org/10.1111/j.14679280.2005.01641.

[5] Ent, M. R., Baumeister, R. F., \& Tice, D. M. 2015 Trait Self-control and the Avoidance of Temptation. Personality and Individual Differences, 74, 12-15. https://doi.org/10.1016/j.paid.2014.09.031.

[6] Fascaly, S. I. 2015. Hubungan Dukungan Sosial dan Penyesuaian Diri pada Santri Pondok Pesantren Terpadu X Kuningan Jawa Barat. Thesis. Yogyakarta: Fakultas Psikologi dan Ilmu Sosial Budaya, Universitas Islam Indonesia.

[7] Jensen, A. R. 1998. The Science of Mental Ability.

[8] Komarraju, M., Ramsey, A., \& Rinella, V. 2013. Cognitive and Non-cognitive Predictors of College 
Readiness and Performance: Role of Academic Discipline. Learning and Individual Differences, 24, 103-109. https://doi.org/10.1016/j.lindif.2012.12.007.

[9] Maddux, J. E. 2009. Self-efficacy, Adaptation, and Adjustment: Theory, Research, and Application. The Plenum Series in Social/Clinical psychology. https://doi.org/10.1007/978-1-4419-6868-5.

[10] Neisser, U., Boodoo, G., Bouchard, T. J. J., Boykin, A. W., Brody, N., Ceci, S. J., Urbina, S. 1996. Intelligence: Knowns and Unknowns. American Psychologist, 51(2), 77-101. https://doi.org/10.1037/0003-066X.51.2.77.

[11] Richardson, M., Abraham, C., \& Bond, R. 2012. Psychological Correlates of University Students' Academic Performance: A Systematic Review and Meta-analysis. Psychological Bulletin, 138(2), 353387. https://doi.org/10.1037/a0026838.

[12] Riglin, L., Frederickson, N., Shelton, K. H., \& Rice, F. 2013. A Longitudinal Study of Psychological Functioning and Academic Attainment at the Transition to Secondary School. Journal of Adolescence, 36, 507517. https://doi.org/10.1016/j.adolescence.2013.03.002.

[13] Robbins, S. B., Lauver, K., Le, H., Davis, D., \& Carlstrom, A. 2004. Do Psychosocial and Study Skill Factors Predict College Outcomes? A Meta-Analysis, 130(2), 261-288. https://doi.org/10.1037/00332909.130.2.261.

[14] Rohde, T. E., \& Thompson, L. A. 2007. Predicting Academic Achievement with Cognitive Ability. Intelligence, $35(1), \quad 83-92$. https://doi.org/10.1016/j.intell.2006.05.004.

[15] Runyon, R.P., \& Haber, A. 1984. Psychology of Adjustment. Illinois: The Dorsey Press.

[16] Stadler, M., Aust, M., Becker, N., Niepel, C., \& Greiff, S. 2016. Choosing between What You Want Now and What You Want Most: Self-control Explains Academic Achievement Beyond Cognitive Ability. PAID, 94, 168-172. https://doi.org/10.1016/j.paid.2016.01.029.

[17] Sulisworo Kusdiyati, \& Lilim Halimah, F. 2011. Penyesuaian Diri di Lingkungan Sekolah pada Siswa Kelas XI SMA Pasundan 2 Bandung. Humanitas, 8(2), 171-194.

[18] Supriyantini, L. S. 2006. Penyesuaian Diri Anak di Sekolah. Psikologia, 2(1), 25-30. Retrieved from http://repository.usu.ac.id/xmlui/handle/123456789/157 22.

[19] Tangney, J. P., Baumeister, R. F., \& Boone, A. L. 2004a. High Self-Control Predicts Good Adjustment, Less Pathology, Better Grades, and Interpersonal Success. Journal of Personality, 72(2), 271-324. https://doi.org/10.1111/j.0022-3506.2004.00263.

[20] Tangney, J. P., Baumeister, R. F., \& Boone, A. L. 2004b. High Self-Control Predicts Good Adjustment, Less Pathology, Better Grades, and Interpersonal Success. Journal of Personality, 72(2), 271-324. https://doi.org/10.1111/j.0022-3506.2004.00263.

[21] Vohs, K. D., \& Baumeister, R. F. 2004. Self-Control. Encyclopedia of Applied Psychology (pp. 369-373). https://doi.org/10.1016/B0-12-657410-3/00165-3.

[22] Zimmerman, B. J., \& Kitsantas, A. 2014. Comparing Students' Self-discipline and Self-regulation Measures and Their Prediction of Academic Achievement. Contemporary Educational Psychology, 39(2), 145155. https://doi.org/10.1016/j.cedpsych.2014.03.004. 